\title{
Analisis Keterampilan Interpersonal Anak Usia 4-5 Tahun Di Sentra Bermain Peran RA Baiturrahman
}

\author{
Gina Nurdiani ${ }^{1}$, Sumardi $^{2}$, Yasbiati $^{3}$, Gilar Gandana $^{4}$ \\ Program Studi Pendidikan Guru Pendidikan Anak Usia Dini \\ Fakultas Keguruan dan Ilmu Pendidikan \\ Universitas Pendidikan Indonesia Kampus Tasikmalaya \\ Email: ginanurdiani97@gmail.com
}

\begin{abstract}
Abstrak
Penelitian ini dilatar belakangi adanya permasalahan mengenai keterampilan interpersonal anak. Keterampilan interpersonal merupakan suatu kemampuan seseorang dalam berhubungan antar perseorangan dimana anak mampu menggali/menerima informasi, mampu merespon informasi dan mampu membangun hubungan yang harmonis.Namun dilapangan masih ada beberapa anak yang belum optimal dalam menggali/menerima informasi, merespon dan membangun hubungan sosial. Oleh karena itu peneliti mengambil fokus kajian pada keterampilan interpersonal anak usia 4-5 tahun. Penelitian ini dilakukan di Sentra Bermain Peran RA Baiturrahman dengan tujuan untuk mengukur, menganalisis, dan mendeskripsikan keterampilan interpersonal anak usia 4-5 tahun di Sentra Bermain Peran RA Baiturrahman menggunakan penelitian deskriptif melalui pendekatan kuantitatif.Sampel yang digunakan dalam penelitian ini berjumlah 10 anak. Alat pengumpulan data dalam penelitian ini adalah observasi dan dokumentasi. Hasil temuan penelitian ini dinyatakan bahwa 1) keterampilan interpersonal anak usia 4-5 tahun di sentra bermain peran RA Baiturrahman berada pada kategori Berkembang Sangat Baik dengan persentase $80 \%$ dari keseluruhan anak; 2) keterampilan interpersonal anak usia 4-5 tahun di sentra bermain peran RA Baiturrahman pada aspek kemampuan menggali/menerima informasi berada pada kategori Berkembang Sesuai Harapan (BSH); 3) keterampilan interpersonal anak usia 4-5 tahun di sentra bermain peran RA Baiturrahman pada aspek kemampuan merespon informasi berada pada kategori Berkembang Sangat Baik (BSB); 4 keterampilan interpersonal anak usia 4-5 tahun di sentra bermain peran RA Baiturrahman berada pada aspek kemampuan membangun hubungan yang harmonis berada pada kategori Berkembang Sangat Baik (BSB). Temuan tersebut dibuktikan dari hasil analisis data yang telah diolah dari data-data yang didapat selama lima pertemuan penelitian.
\end{abstract}

Kata Kunci : Keterampilan Interpersonal, Anak Usia 4-5 Tahun, Sentra Bermain Peran.

Abstract
This research is motivated by problems regarding children's interpersonal skills. Interpersonal
skills are a person's ability to connect between individuals where children are able to dig /
receive information, are able to respond to information and are able to build harmonious
relationships. But in the field there are still some children who have not been optimal in digging
/ receiving information, responding and building social relationship. Therefore the researchers
took a focused study on the interpersonal skills of children aged $4-5$ years. Research is
conducted at the Role Play Center RA Baiturrahman with the purpose to measure, analyze, and
describe the interpersonal skills of children aged 4-5 years at Role Play Center RA
Baiturrahman using research descriptive with approach quantitative. The sample used in this
study amounted to 10 children. The data collection tool in this study is observation and 
documentation. The findings of this study stated that 1) interpersonal skills of children aged 4-5 years in RA Baiturrahman's role playing center are in the Very Good Developing category with a percentage of $80 \%$ of all children; 2) interpersonal skills of children aged 4-5 years in RA Baiturrahman's role playing center on aspects of the ability to dig / receive information are in the Expectation Developing (BSH) category; 3) interpersonal skills of children aged 4-5 years in RA Baiturrahman's role playing center on aspects of the ability to respond to information in the Very Good Developing category (BSB); 4 interpersonal skills of children aged 4-5 years in RA Baiturrahman's role playing center are in the aspect of the ability to build harmonious relationships in the Very Good Developing category (BSB). These findings are proven from the results of data analysis that has been processed from the data obtained during five research meetings.

Keywords: Interpersonal Skills, Children Ages 4-5 Years, Role Play Center .

\section{PENDAHULUAN}

Pendidikan merupakan hal yang sangat penting bagi kehidupan.Pendidikan secara tidak langsung memberikan andil yang sangat besar bagi kehidupan. Dengan adanya pendidikan dapat terwujudnya pengetahuan, sikap, dan keterampilan yang dibutuhkan sesuai apa yang diperlukan. Seperti yang diungkapkan Sujiono (2009, hlm 7) bahwa "Pendidikan anak usia dini adalah upaya untuk menstimulasi, membimbing, mengasuh, dan memberikan kegiatan pembelajaran yang akan menghasilkan kemampuan dan keterampilan anak." Dari penjelasan tersebut sudah kita ketahui bahwa pendidikan bisa dikatakan sangat penting karena pendidikan mrupakan bekal awal bagi anak usia dini dalam mengembangkan berbagai potensi.Anak usia dini adalah anak yang sedang menjalani suatu proses perkembangan dengan pesat dan fundamental bagi kehidupan selanjutnya. Masa anak usia dini sering disebut dengan usia keemasan (The Golden Age), dimana pada masa tersebut berbagai potensi yang dimiliki anak dapat berkembang secara optimal baik dalam aspek kognitif, bahasa, fisik motorik, moral agama, seni dan sosial emosionalnya. Usia keemasan ini hanya datang satu kali dan tidak dapat diulang lagi. Oleh karena itu peluang atau kesempatan ini hendakya dimanfaatkan sebaik-baiknya untuk pembelajaran anak, karena rasa ingin tau anak dalam usia emas berada pada posisi puncak dan mempunyai potensi yang lebih besar untuk mengoptimalkan segala aspek keterampilan ataupun kecerdasan. Lingkungan sekeliling anak juga seperti keluarga, sekolah dan masyarakat sekitar sangat penting untuk membantu dan memberikan berbagai stimulus-stimulus kepada anak sebagai upaya pengoptimalan pertumbuhan dan perkembangan yang dimiliki anak.

Permendikbud RI No. 137 tahun 2014 Pasal 10 tertulis bahwa "Lingkup perkembangan sesuai anak meliputi aspek agama dan moral, fisik motorik, kognitif, bahasa, sosial emosional dan seni." Perkembangan sosial merupakan salah satu aspek dalam ruang lingkup perkembangan anak usia dini. Jika perkembangan sosial yang baik maka akan menunjang keterampilan sosial yang baik juga. Keterampilan sosial anak sangatlah diperlukan bagi kehidupan bersosial. Anak yang memiliki keterampilan sosial yang baik akan lebih efektif dalam menjalankan hubungan sosial dengan lingkungannya. Keterampilan sosial bisa disebut dengan keterampilan interpersonal dimana keterampilan interpersonal merupakan kemampuan seseorang dalam berhubungan sosial.

Keterampilan interpersonal merupakan kemampuan berhubungan atau berinteraksi dengan orang lain untuk memahami perasaan, suasana hati, serta mengerti apa yang orang lain inginkan. (Musfiroh, 2008). Keterampilan interpersonal juga merupakan keterampilan yang harus dimiliki seseorang dalam menjalin hubungan antarpribadi (Fitriani, M.R \& Hidayah, N. ). Keterampilan Interpersonal sangatlah penting khususnya bagi anak usia dini, 
menjadi penting karena pada dasarnya manusia tidak bisa hidup sendiri. Permendikbud No 137 terdapat indikator pencapaian perkembangan anak usia 4-5 tahun dalam aspek sosial diantaranya: anak mampu bersikap sopan baik itu melalui perkataan maupun perbuatannya, misalnya mampu mengucapkan salam, mampu mengucapkan maaf, dan mampu mengucapkan terimakasih; anak menunjukkan sikap mau menolong satu sama lain; mampu memecahkan masalah sederhana ketika dihadapkan dengan masalah-masalah kecil; mau menjalin pertemanan dengan baik; mampu meminta bantuan kepada orang lain saat menghadapi kesulitan ataupun hal yang tidak bisa anak lakukan; mampu menunjukkan sikap mengendalikan perasaan; dan menunjukkan rasa percaya diri dalam membantu temannya.

Pendidikan anak usia dini merupakan pemberian upaya pembinaan untuk membantu pertumbuhan dan perkembangan anak baik itu jasmani maupun rohani. Pendidikan anak usia dini ini ditujukkan pada anak sejak lahir sampai usia enam tahun. Selain itu pendidikan anak usia dini merupakan bagiandari pencapaian tujuan pendidikan nasional yaitu dalam mencerdaskan kehidupan bangsa dan mengembangakn manusia Indonesia yang seutuhnya (Sujiono, 2009, hlm 8).Secara umum anak usia dini yaitu anak-anak yang berusia dibawah 6 tahun. Usia tersebut termasuk dalam usia emas, seperti yang dikemukakan dalam Healthline Pacific Cross "Golden Age atau fase emas adalah fase saat otak anak mengalami perkembangan yang paling cepat dalam pertumbuhannya, kurang lebih $80 \%$ otak anak mengalami perkembangan pada usia 0-6 tahun."Beberapa ahli dalam bidang pendidikan memandang perkembangan anak usia dini adalah periode yang sangat penting dan perlu mendapat penanganan sedini mungkin agar kemampuan anak berkembang secara optimal berdasarkan aspek-aspek perkembangan anak usia dini (Mulyasa, 2012, hlm. 20).

Permendikbud RI No. 137 tahun 2014 Pasal 10 tertulis bahwa "Lingkup perkembangan sesuai anak meliputi aspek agama dan moral, fisik motorik, kognitif, bahasa, sosial emosional dan seni." Perkembangan sosial merupakan salah satu aspek dalam ruang lingkup perkembangan anak usia dini. Jika perkembangan sosial yang baik maka akan menunjang keterampilan sosial yang baik juga.

$$
\text { Goleman (2001) menyatakan }
$$

bahwa keterampilan sosial berkaitan dengan kecerdasan emosional, dimana dalam kecerdasan emosional terdapat hubungan sosial yang disebut dengan interpersonal.keterampilaninterpersonal merupakan suatu kemampuan seseorang dalam berhubungan antar perseorangan. Musfiroh (2008, hlm 17) bahwa keterampilan interpersonal ditandai dengan kemampuan mencerna dan merespon secara tepat suasana hati, temperamen, motivasi dan keinginan orang lain. sejalan dengan yang dikemukakan oleh Satrianti, A (2013) bahwa keterampilan interpersonal merupakan suatu kemampuan seseorang untuk beriteraksi dengan orang lan seperti menjadi pendengar yang baik, menyampaikan pendapat secara jelas dan mampu bekerja dalam satu tim. Sejalan dengan penjelasan tersebut ahli lainnya menyatakan bahwa keterampilan interpersonal merupakan suatu keterampilan untuk mengenali, memahami, dan merespon perasaan secara baik, memahmi perilaku dan sikap orang lain, serta mampu dalam memotivasi dalam memaham keinginan orang lain. Mork (dalam Yaumi, 2013, hlm 131) menyatakan bahwa keterampilan interpersonal menekankan pada empat elemen penting yang perlu digunakan dalam membangun komunikasi, diantaranya: (1) membaca isyarat sosial, (2) memberikan empati, (3) mengontrol emosi, dan (4) mengekspresikan emosi pada tempatnya. Komponen inti keterampilan interpersonal adalah kemampuan menggali, mencerna dan menanggapi dengan tepat berbagai suasana hati, maksud, motivasi, perasaan, dan gagasan orang lain. Mereka yang mempunyai keterampilan interpersonal akan mampu menjain komunikasi yang efektif dengan orang lain. Dari berbagai pendapat dapat disimpulkan bahwa keterampilan interpersonal merupakan 
kemampuan seseorang dalam berhubungan sosial ataupun interaksi untuk memahami perasaan dan sikap orang lain, serta dalam berinteraksi maupun berhubungan sosial anak mampu menggali/menerima suatu informasi, merespon dan membangun hubungan yang baik ataupun harmonis dengan orang lain.

Anderson (dalam Safaria, 2005) menjelaskan bahwa keterampilan interpersonal memiliki 3 dimensi, diantaranya: Sensitivitas Sosial, Pemahaman Sosial, dan Komunikasi Sosial. Dalam keterampilan interpersonal anak usia dini terdapat beberapa faktor yang dapat mempengaruhi keterampilan interpersonal anak diantaranya: keluarga, teman sebaya dan sekolah (Rustandi, 2017.hlm 17). Ketiga faktor tersebut merupakan pengaruh yang dapat mempengaruhi perilaku anak khususnya pada keterampilan interpersonal anak.

Keterampilan interpersonal terlihat dari bagaimana seseorang berkomunikasi atau berhubungan dengan orang lain. Salah satu yang dapat dilakukan untuk mengetahui keterampilan interpersonal anak yaitu dengan melihat karakteristik yang ada pada orang tersebut.

$\begin{array}{lr}\text { Beberapa } & \text { karakteristik } \\ \text { keterampilan interpersonal yang }\end{array}$
dikemukakan Suparno, P. (2013, hlm. 4748) diantaranya:Kemampuan berempati pada temannya; Mudah bekerjasama dengan orang lain; Mudah mengenal dan membedakan perasaan pribadi dan orang lain; Kemampuan menggali/menerima informasi; Mampu merespon; Mengorganisasi teman-temannya untuk melakukan tugas; Memiliki banyak teman dan mampu menjalin hubungan dengan teman-temannya; Sering menjadi pemimpin diantara teman-temannya; Memiliki perhatian yang besar. Adapun menurut Musfiroh (2008, hlm 1.18) tanda utama atau karakteristik keterampilan interpersonal yaitu "anak yang sangat menyenangkan bagi temannya". Diantaranya anak peka terhadap perasaan; senang menjalin kontak seperti menyapa, bertanya, menjawab ataupun mengucapkan terimakasih;mau bekerja sama dengan orang lain; dan anak mau mengorganisasi dalam perumusan peraturan penyelesaian tugas serta cenderung memimpin.

Sentra Bermain Peran merupakan tempat atau pusat dimana anak melakukan kegiatan untuk meniru perilaku yang diperankan.Pembelajaran bermain peran terletak pada keterlibatan emosionalpemeran dan pengamat dalam situasi masalah yang secara nyata dihadapi.Kegiatan bermain peran memberikan kesempatan kepada anak untuk menciptakan situasi khayalan dimana anak diberi kesempatan untuk bereksplorasi dengan suatu objek dan melakukan kegiatan sesuai dengan karakter objek tersebut.Dengan bermain peran juga terdapat manfaat untuk memupuk adanya pemahaman peran sosial dan melibatkan interaksi verbal serta membantu anak untuk mempelajari lebih dalam mengenai dirinya sendiri, keluarga, dan masyarakat sekitar (Montolalu, 2005).Manfaat bermain peran yaitu sebagai sarana bagi anak untuk belajar dari orang lain, mengembangkan kemampuan anak untuk berkomunikasi, membuat anak lebih mampu untuk bersosialisasi, dan membantu anak mengembangkan persahabatan (Yuliani, 2009).

\section{METODOLOGI PENELITIAN}

Metode penelitian ini yaitu metode penelitian deskriptif.Menurut Sugiyono (dalam Rustandi, D.F. 2017) menjalaskan bahwa metode deskriptif adalah metode yang dimaksudkan untuk mencari informasi, memaparkan apa yang sedang terjadi dilapangan. Penelitian ini disusun dengan menggunakan pendekatan penelitian kuantitatif.Pendekatan kuantitatif adalah penelitian dimana data berupa angka dan dianalisis menggunakan statistik.

Populasi yang digunakan dalam penelitian ini adalah anak usia 4-5 tahun di Sentra Bermain Peran RA Baiturrahman Kota Tasikmalaya. Jumlah sampel yang diteliti adalah 10 orang anak dari 18 orang anak di Kelas A1 Sentra Bermain Peran RA Baiturrrahman.Dalam penelitian ini, peneliti menggunakan teknik pengumpulan data dengan observasi dan dokumentasi.Analisis data dilakukan pada hasil data yang terdapat berdasarkan 
instrumen observasi yang dilakukan oleh observer dengan memberikan tanda checklist pada skala kemunculan yang sesuai.

\section{HASIL PENELITIAN DAN PEMBAHASAN}

Penelitian ini bertujuan untuk mengukur, menganalisis dan mendeskripsikan ketarmpilan interpersonal anak usia 4-5 tahun di Sentra Bermain Pearan RA Baiturrahman. Berdasarkan hasil penelitian yang telah dilakukan, Hasil penelitian terhadap temuan keterampilan interpersonal anak usia 4-5 tahun di sentra bermain peran RA Baiturrahman diantaranya:

1) Aspek kemampuan menggali informasi/menerima informasi berada pada kategori Berkembang Sesuai Harapan (BSH) dengan nilai rata-rata 5,1. Walaupun dari hasil rata-rata aspek kemampuan menggali/menerima informasi berada pada kategori berkembang sesuai harapan, masih ada anak yang kemampuan menggali informasi/menerima informasi dalam berinteraksi belum berkembang secara optimal yaitu pada indikator dalam menyapa dan bertanya saat ada hal yang tidak dipahami kepada temannya, namun pada indikator dalam menyapa dan bertanya saat ada yang tidak dipahami kepada guru sudah sesuai harapan. Hal tersebut jika dilihat saat observasi bisa dipengaruhi dari faktor teman sebaya yang hubungan dengan temannya kurang baik sehingga anak kurang dalam berinteraksi dengan temannya, hal tersebut seperti yang dikemukakan oleh Rustandi. D.F (2017,hlm 17) bahwa salah satu faktor yang mempengaruhi keterampilan interpersonal baik itu dalam aspek menggali/menerima informasi yaitu teman sebaya. Walaupun masih ada anak yang kurang optimal dalam menggali informasi/menerima informasi dalam berinteraksi. Di sentra bermain peran yang ada di RA Baiturrahman mempengaruhi perkembangan tersebut, yang sejalan dengan manfaat bermain peran bahwa bermain peran merupakan sarana bagi anak untuk belajar dengan orang lain untuk berkomunikasi dan bersosialisasi. Dalam bermain peran tentunya ada kegiatan berinteraksi dengan temannya. Adapun hasil temuan yang telah dipaparkan pada bab temuan aspek kemampuan menggali informasi/menerima informasi dalam berinteraksi sudah berkembang dengan baik walaupun ada beberapa yang masih belum optimal. Maka dari itu meskipun sentra tersebut dapat melatih anak dalam keterampilan interpersonal, beberapa faktor pendukung lainnya juga harus mendukung guna meningkatkan keterampilan interpersonal anak.

2) Pada aspek kemampuan meresponinformasi berada pada kategori Berkembang Sangat Baik (BSB). Pada aspek ini mayoritas sudah mampu mencapai dalam merespon informasi. Dalam aspek ini anak sudah mampu merespon informasi dalam berinteraksi dengan guru dan mampu merespon informasi dalam berinteraksi dengan temannya yang didalamnya anak mengucapkan terimakasih kepada guru yang sudah menolong dirinya, anak menjawab sapaan dari guru,anak mengucapkan terimakasih kepada teman yang sudah menolong dirinya, dan anak menjawab sapaan dari teman. Hal itu dipengaruhi oleh beberapa faktor salah satunya kegiatan bermain peran yang ada di sentra bermain peran RA Baiturrahman.Selain itu pada aspek ini dominan anak-anak sudah mencapai semua aspek walau ada sedikit yang belum tercapai. Pada lima pertemuan penelitian dalam kegiatan bermain peran anak dilatih dengan memerankan sebuah peran yang mampu menstimulus aspek kemampuan merespon informasi. Anak mampu mengucakan terimakasih kepada guru ataupun teman yang telah menolong dirinya saat kesususahan dalam bermain peran dan menjawab sapaan temannya saat bermain peran tersebut pula.Seperti teori Rustandi (2017, hlm 17) beberapa faktor yang dapat mempengaruhi keterampilan interpersonal diantaranya pengaruh dari keluarga, teman sebaya, maupun sekolah.

3) Aspek kemampuan meresponinformasi berada pada kategori Berkembang Sangat Baik (BSB). pada aspek ini mayoritas anak sudah mampu berkembang dengan baik walaupun masih ada beberapa anak yang belum mencapai item secara optimal. 
Dalam aspek kemempuan membangun hubungan yang harmonis terdapat dua indikator yaitu mampu membangun hubungan yang harmonis berdasarkan kesadaran diri dan mampu membangun hubungan yang harmonis dalam melakukan musyawarah. Terdiri dari beberapa indikator yaitu anak mengucapkan salam pada guru, anak mengucapkan salam pada teman, anak mengucapkan salam saat masuk kelas, anak menjawab salam dari guru, anak menjawab salam dari teman, anak mampu menceritakan pengalamannya kepada guru, anak mampu menceritakan pengalamannya kepada temannya, anak memimpin diskusi dengan temannya sebelum bermain, dan anak merumuskan peraturan penyelesaian tugas bersama temannya sebelum bermain dilakukan.

4) Hasil penelitian yang telah dilakukan menunjukkan bahwa keterampilan interpersonal anak usia 4-5 tahun di Sentra Bermain Peran RA Baiturrahman berada pada kategori Berkembang Sangat Baik (BSB). Hal tersebut juga bisa dipengaruhi oleh beberapa faktor, seperti stimulasi yang diberikan pada anak dalam pengembangan keterampilan interpersonal baik itu dari keluarga maupun lingkungan sekolah. Stimulasi yang dapat dilakukan dalam keluarga mislanya membangun hubungan yang baik. Dengan membangun hubungan yang baik anak akan merasa percaya diri, merasa didukung dan akan merasa bahwa anak tersebut mempunyai kepercayaan diri. Sehingga dalam berhubungan dengan orang lain anak tidak canggung ataupun malu. Selain itu kegiatan yang bisa mengembangkan keterampilan interpersonal anak salah satunya adalah bermain peran.Seperti Wee, dkk (2013) menyatakan bahwa "kegiatan yang bisa mengembangkan keterampilan interpersonal adalah kegiatan bermain peran Dengan bermain peran anak dapat mengembangkan keterampilan dalam pemecahan masalah, menjalin hubungan yang baik, memahami perasaan orang lain, mengendalikan emosi, dan melatih berinteraksi dalam merespon informasi dalam berinteraksi."

Namun terlepas dari itu masih ada anak yang masih kurang dalam kemampuan menggali/menerima informasi pada item kemampuan menggali/menerima informasi dalam berinteraksi dengan temannya, hal itu dipicu oleh beberapa faktor misalnya faktor teman sebayanya yang masih memilih-milih teman sehingga anak tersebut menjadi sungkan untuk berinteraksi.Faktor dari dalam dirinya sendiri seperti pemalu, pendiam dan sebagainya. Faktor lainnya juga bisa dipicu dari keluarga , misalnya orang tua yang sibuk dengan pekerjaannya sehingga anak kurang berinteraksi dalam membangun suatu hubungan yang baik. Hal tersebut tidak sejalan dengan teori Suparno (2013, hlm. 47-48) yang menyebutkan bahwa karakteristik anak dalam keterampilan interpersonal anak salah satunya yaitu mampu menggali/menerima informasi.

\section{SIMPULAN}

Berlandaskan hasil penelitian yang telah dilakukan di Sentra Bermain Peran RA Baiturrahman terkait tingkat keterampilan interpersonal anak usia 4-5 tahun, peneliti dapat mengambil simpulan sebagai berikut:

1. Keterampilan Interpersonal anak usia 45 tahun di Sentra Bermain Peran RA Baiturrahman termasuk dalam kriteria BSB (Berkembang Sangat Baik).

2. Keterampilan Interpersonal anak usia 45 tahun di Sentra Bermain Peran RA Baiturrahman dalam aspek kemampuan menggali informasi/menerima informasi termasuk dalam kriteria $\mathrm{BSH}$ (Berkembang Sesuai Harapan). Namun jika dilihat dari nilai rata-rata pada aspek inilah yang masih kurang optimal.

3. Keterampilan Interpersonal anak usia 45 tahun di sentra bermain peran RA Baiturrahman dalam aspek kemampuan merespon informasi termasuk dalam kriteria BSB (Berkembang Sangat Baik).

4. Keterampilan Interpersonal anak usia 45 tahun di sentra bermain peran RA Baiturrahman dalam aspek kemampuan membangun hubungan yang harmonis termasuk dalam kriteria BSH (Berkembang Sesuai Harapan).

\section{DAFTAR PUSTAKA}


Alif, A. \& Wulantika, W. Penerapan Pembelajaran Berbasis Sentra Bermain Peran terhadap Perkembangan Sosial Emosional Pada Anak Usia Prasekolah. Jurnal Seminar Nasional Pendidikan. hlm 31-33

Amelia, L \& Marsella, A. (2018). Meningkatkan Kemampuan Interpersonal Melalui Metode Bermain Peran dengan Menggunakan Boneka Jari Pada Anak TK B2 di PAUD Save The Kids Banda Aceh. Jurnal Buah Hati, Vol. 5, No. 2

Amri, N. A. (2017). Pengaruh Metode Bermain Peran Terhadap Kemampuan Komunikasi (Bahasa Ekspresif) Anak Taman KanakKanak Raudhatul Athfal Alauddin Makassar. Jurnal Ilmu Pendidikan, Keguruan, dan Pembelajaran, Vol. 1, No. 2, hlm. 105

Creswell, J.W. (2010). Research Design Pendekatan Kualitatif, Kuantitatif, dan Mixed. Yogyakarta : Pustaka Pelajar

Fitriani, M.R. \& Hidayah,N. (2016). Keefektifan Konseling Kelompok Adler untuk Meningkatkan Keterampilan Interpersonal.Jurnal Kajian Bimbingan dan Konseling, Vol. 1, No. 1, hlm 7-8.

Gandana, G. (2015). Meningkatkan Kecerdasan Emosional Anak Usia Dini Melalui Permainan Tradisional "Kaulinan Barudak". Universitas Pendidikan Indonesia, Tasikmalaya

Goleman. (2001). Kecerdasan Emosi Untuk Mencapai Puncak Prestasi.

Hadiningrum, A \& Widayati, S. (2014). Jurnal Studi Deskriptif Kepercayaan Diri Melalui Sentra Bermain Peran.

Hethline Pacific Cross. (...). Golden Age Fase Emas. Jakarta : PT. International Pacific Cross

Mujahidah,H.N. (2016). JurnalKegiatan Bermain Peran Makro Dalam Upaya Mengembangkan Kecerdasan Linguistik Pada Anak Usia Dini Kelompok B Di TK
Aisyiyah Hadimulyo Metro Barat. Universitas Lampung, Bandar Lampung.

Montolalu, dkk. (2005). Bermain dan Permainan Anak. Universitas Terbuka : Jakarta

Musfiroh, T. (2008). Pengembangan Kecerdasan Majemuk. Banten : Universitas Terbuka

Peraturan Menteri Pendidikan dan Kebudayaan Republik Indonesia No. 137 Tahun 2014

Rahmawati,C.W. (2015). Identifikasi Kecerdasan Interpersonal Anak Usia 4-5 Tahun di TK Gugus Sido Mukti Kecamatan Mantrijeron Kota Yogyakarta.Jurnal Pendidikan Anak Usia Dini.

Rustandi, D.F. (2017). Kemampuan Interpersonal Anak Usia Dini. (Skripsi). Sekolah Strata-1, Universitas Pendidikan Indonesia Kampus Tasikmalaya, Kota Tasikmalaya.

Safaria, T. (2005). Interpersonal Intelligence. Yogyakarta : Amara Books

Satriani, A. (2013). Keterampilan Interpersonal. Diakses dari : https://alfisatrianti.wordpress.com/2 013/06/26/interpersonal-skillketerampilan-interpersonal/.

Sugiyono. (2016). Metode Penelitian Kuantitatif, Kulitatif, dan $R \& D$. Bandung : Alfabeta

Sujiono, Y.N. (2009). Konsep Dasar Pendidikan Anak Usia Dini. Jakarta : Permata Puri Media

Suparno, P. (2013). Teori Intelligensi Ganda dan Aplikasinya di Sekolah. Yogyakarta : Kanisius

Sundari. (2012). Peningkatan Rasa Percaya Diri Melalui Bermain Peran Pada Anak Kelompok B di TK Pertiwi 03 Tambak. Universitas Muhammadiyah Surakarta, Boyolali.

Vatmala, T. (2017). Jurnal Mengembangkan Kecerdasan Interpersonal Anak Usia Dini Melalui Metode Bermain Peran di PAUD Bina Insani Lambu Kibang Tulang Bawang Barat. Lampung 
Wee, S., dkk (2013) Young children's Role-playing for Enhancing Personal Intelligences in Multiple Theory. International Research in Early Childhood Education. Vol. 4, No. 1, Page 53.

Yaumi, M. (2012). Pembelajaran Berbasis Multiple Intelligences. Jakarta : Dian Rakyat

Yunita, H. (2017). Kecerdasan Interpersonal Anak Usia 4-5 Tahun di TK Alphabet Kecamatan
Cihideng Kota Tasikmalaya. (Skripsi). Sekolah Strata-1, Universitas Pendidikan Indonesia, Tasikmalaya.

Yusuf, M. (2014). Metode Penelitian Kuantitatif, Kualitatif dan Penelitian Gabungan. Jakarta : Prenadamedia Group

Zahro. (2015). Jurnal Penilaian Dalam Pembelajaran Anak Usia Dini. STKIP Siliwangi. Vol. 1, No.1,hlm.14. 